NBER WORKING PAPER SERIES

\title{
RENEGOTIATION WITHOUT HOLDUP: ANTICIPATING SPENDING AND INFRASTRUCTURE CONCESSIONS
}

\author{
Eduardo Engel \\ Ronald Fischer \\ Alexander Galetovic \\ Working Paper 12399 \\ http://www.nber.org/papers/w12399
NATIONAL BUREAU OF ECONOMIC RESEARCH
1050 Massachusetts Avenue
Cambridge, MA 02138
July 2006

Engel: Yale University and NBER. Fischer: Center of Applied Economics (CEA), University of Chile. Galetovic: Facultad de Ciencias Económicas y Empresariales, Universidad de los Andes. E-mails: eduardo.engel@yale.edu, rfischer@dii.uchile.cl, agaleto@uandes.cl. The views expressed herein are those of the author(s) and do not necessarily reflect the views of the National Bureau of Economic Research.

(O2006 by Eduardo Engel, Ronald Fischer and Alexander Galetovic. All rights reserved. Short sections of text, not to exceed two paragraphs, may be quoted without explicit permission provided that full credit, including $\odot$ notice, is given to the source. 
Renegotiation Without Holdup: Anticipating Spending and Infrastructure Concessions Eduardo Engel, Ronald Fischer and Alexander Galetovic

NBER Working Paper No. 12399

July 2006

JEL No. H21, L51, L91

\title{
ABSTRACT
}

Infrastructure concessions are frequently renegotiated after investments are sunk, resulting in better contractual terms for the franchise holders. This paper offers a political economy explanation for renegotiations that occur with no apparent holdup. We argue that they are used by political incumbents to anticipate infrastructure spending and thereby increase the probability of winning an upcoming election.

Contract renegotiations allow administrations to replicate the effects of issuing debt. Yet debt issues are incorporated in the budget, must be approved by Congress and are therefore subject to the opposition's review. By contrast, under current accounting standards the obligations created by renegotiations circumvent the budgetary process in most countries. Hence, renegotiations allow incumbents to spend more without being subject to Congressional oversight.

\author{
Eduardo Engel \\ Department of Economics \\ Yale University \\ Box 208268 Yale Station \\ New Haven, CT 06520-8268 \\ and NBER \\ eduardo.engel@yale.edu \\ Ronald Fischer \\ University of Chile \\ Center for Applied Economics (CEA) \\ Republica 701 \\ Santiago \\ CHILE \\ rfischer@dii.uchile.cl \\ Alexander Galetovic \\ Universidad de los Andes \\ Fac. Cs. Economicas y Empresariales \\ San Carlos de Apoquindo 2200 \\ Santiago \\ CHILE \\ agaletovic@uandes.cl
}




\section{Introduction and motivation}

Incomplete contract theory (e.g. Hart, 1995) suggests that the party which sinks an investment is vulnerable to opportunism by its counterpart. It is thus surprising to find that this argument seems to stand on its head when it comes to infrastructure concessions granted by governments to private companies: it is routine for franchise holders to renegotiate better contract terms after building and sinking the infrastructure.

Guasch (2004) has examined nearly 1,000 Latin American concession contracts awarded between the mid 1980s and 2000 . He found that $30 \%$ of all contracts were renegotiated and that this percentage increases to $54.4 \%$ in the transportation sector (roads, ports, tunnels and airports) and to $74.4 \%$ in the water sector. Table 1 , which we reproduce from his book, shows that renegotiations often favor the firm at the expense of the rest of society. For example, $62 \%$ of renegotiations led to tariff increases, $38 \%$ to extensions of the concession period and $62 \%$ to reductions in investment obligations. Renegotiations do not only occur in developing countries. ${ }^{2}$ Gómez-Ibáñez and Meyer (1993) analyze transportation concessions in many industrialized countries and find that renegotiations are also common.

Pervasive renegotiations that benefit franchise holders beg an explanation, because governments could easily switch managers after a project is built, so threats by the concessionaire to abandon the franchise should be empty. ${ }^{3}$ Thus it appears that renegotiations occur without a holdup problem! ${ }^{4}$ Of course, there is no question that corruption and incompetence may partly explain why governments accept to renegotiate in favor of franchise holders. But that cannot be the full explanation, because contracts are renegotiated in countries of widely differing institutional strength and corruption levels.

In this paper we propose a complementary explanation for renegotiations that favor concessionaires and which take place after the infrastructure is built. We present a simple political

\footnotetext{
${ }^{2}$ Guasch, Laffont and Straub (2003) estimate the probability of renegotiation, for approximately 300 concessions in the transportation and water sectors, as a function of regulatory institutions, institutional features, economic shocks and the characteristics of the contracts themselves. Their findings are broadly consistent with the implications of the reduced form regulation model they present. By contrast with Guasch et al (2003), we focus on an explanation for pervasive renegotiations not considered in their paper and develop a more detailed model for this source of renegotiations.

${ }^{3}$ This holds for projects where a takeover of operations by the government does not require advanced skills in order to maintain deterioration in the service quality because the franchise holder's informational advantage in the operation of the infrastructure is small. This is the case, for example, for highways, but not for a sewage system.

${ }^{4}$ We do not claim that received theory necessarily implies government expropriations-after all, normal governments are interested in attracting investments in the future, and this is not helped by a reputation of expropriating franchise holders. But we want to stress that the standard explanation, holdup, does not seem to be relevant for renegotiations that favor the party with the sunk investment, since the government favors the firm beyond the terms of the original contract.
} 
Table 1: Renegotiation Outcomes (GuAsch, 2004)

\begin{tabular}{lc}
\hline Renegotiation outcome & $\begin{array}{c}\text { Percentage of renegotiated } \\
\text { concession contracts } \\
\text { with }\end{array}$ \\
\hline that outcome
\end{tabular}

economy model in which an administration that spends more on public works is more likely to be reelected. This creates a bias towards anticipating infrastructure spending. The obvious way to anticipate public expenditures is to issue debt. However, issuing debt to finance additional expenditures normally needs to be included in the budget approval process, which often must be negotiated with the opposition. ${ }^{5}$ Knowing that higher expenditures increase the chances of losing the next election, the opposition will attempt to check the tendency to overspend. On the contrary, renegotiations aren't subject to the opposition's scrutiny, because-so far-they are not included in the regular budgetary process. ${ }^{6}$ Thus, we argue, renegotiations are vehicles through which the current administration reaches an agreement with the franchise holder on an intertemporal transfer. The government obtains higher current spending which improves its chances of reelection while the franchise holder obtains better conditions than those in the original contract. The resulting bias toward present spending reduces social welfare and also affects adversely future administrations.

The rest of the paper is organized as follows. Section 2 describes in detail a massive renego-

\footnotetext{
${ }^{5} \mathrm{~A}$ bill to increase spending on the eve of elections that is contested by the opposition may lead to a bad perception by voters.

${ }^{6}$ Also, spending limits imposed by multilateral institutions such as the IMF on countries where the budgetary process is weak generally do not apply to renegotiations.
} 
tiation that occurred in Chile in 2003, illustrating the main mechanism described in this paper. Section 3 formalizes our argument. Section 4 concludes.

\section{A case study: highway renegotiations in Chile}

In the early nineties Chile launched a massive program of infrastructure concessions, which completely renovated its road system, ports and airports. Most of the major pitfalls that have plagued concessions elsewhere were avoided, and the program was successful in upgrading Chile's transport infrastructure. Nevertheless, contract renegotiations have been pervasive. ${ }^{7}$ Here we describe two types of renegotiations that were used to anticipate spending. In the first type, the Ministry of Public Works (MOP by its Spanish acronym) changed the terms of the contract in order to obtain additional works from the concessionaire. In the second type, MOP exchanged an "insurance premium" (i.e. a cash payment made upfront by the concessionaire) for a potential extension of the concession term, which translates into less income for future administrations.

\subsection{Complementary contracts}

In Chile many contracts were renegotiated after construction was underway to include additional works. Twelve out of the sixteen highway projects awarded by 1998 had been renegotiated by May 2002. In total there were 31 modifications to the original contracts, all of them involving the provision of additional infrastructure, with total value of $\$ 518$ million. Initially, these projects were valued at $\$ 3.4$ billion, that is, the average cost increase was $15.4 \%$. More recently, the pattern has held: as of 2005 , renegotiations involved $\$ 1.27$ billion, in additional works, representing approximately $15 \%$ of almost $\$ 9$ billion in projects. ${ }^{8}$ The contracts were renegotiated using so-called complementary contracts with the franchise holder, which were negotiated bilaterally and without public review. ${ }^{9}$ It follows that renegotiations have allowed the

\footnotetext{
${ }^{7}$ In a long term contract the contract may need adjustments in response to unforseen events. This is reasonable, given the difficulties of writing complete contracts, but in this paper we focus on renegotiations that occur early in the life of the contract, or in response to events that were well within the range of possibilities.

${ }^{8}$ In addition, as of 2006 there are US $\$ 523$ million at stake in disputes between the Ministry of Public Works and the franchse holders. Historically, the government ends up paying 30-40\% of the disputed sums (See "Mop y privados en lío arbitral por US\$523 millones", El Mercurio, April 18, 2006.

9 "All the secretaries of public works maintained absolute reserve on the negotiations they carried out with concession holders regarding the financing of additional works required by the projects." La Tercera, April 23, 2006. Also see "Informe de la U. de Chile revela suerte de embaucamiento del MOP a Mideplan." La Segunda, May 13, 2003.
} 
Chilean government to increase expenditure on infrastructure projects significantly. Of course, not all additional projects were a vehicle to anticipate government expenditures. In some cases additional work was needed because of design oversights reflecting the haste with which the projects were developed under political pressure by the government. In other cases, the additional works were necessary because the project was under-designed on purpose, so it would achieve the social rate of return required of all public projects in Chile. In all these cases, the government wanted to build quickly in order to show results before an upcoming election. ${ }^{10}$

\subsection{Ex post insurance}

Most highway concession contracts in Chile were fixed term contracts, normally with a length of 20 to 30 years. Between 1998 and 2002 the economy went into recession and traffic flows grew slower than expected. After several years of losses, franchise holders formed an association that asked the government to renegotiate their contracts.

The government offered a new contract that guaranteed the franchise holder the toll revenue that would have attained if traffic had grown at an annual rate of $\mathrm{x} \%$ (where $\mathrm{x}=4,4.5$ or $5 \%$ and was chosen by the franchise holder) during the lifespan of the contract. If actual revenues were insufficient, the concession would be extended by up to almost 10 years to collect the guaranteed revenue, and if this did not suffice, the government would pay the remaining difference. By contrast, the term could not be shortened, so the firm would benefit from upside risk. In effect, the renegotiation offered an asymmetric variable-term contract as a replacement of the original fixed-term contract. ${ }^{11}$ As Table 2 shows, the total amount of guaranteed income was $\$ 2.2$ billion.

In exchange for the guaranteed income, franchise holders who accepted had to pay an "insurance premium", which totaled $\$ 171$ million, or about $7.8 \%$ of the guaranteed revenue (see Table 2). ${ }^{12}$ Nevertheless, the payment would be made in kind: as additional investments. ${ }^{13}$

\footnotetext{
10 "Probably, the interest of the government and the private sector in building many projects, very fast, explains why the government and the private sector did not anticipate future problems.” Eduardo Bitrán, Secretary of Public Works, describing the shortcomings of the previous administration. La Segunda, April 28, 2006.

${ }^{11}$ While this system resembles the flexible term present-value-of-revenue (PVR) contracts studied in Engel, Fischer and Galetovic (2001), it differs from this proposal in important ways. First, it does not contemplate a competitive auction that dissipates ex ante rents. Second, firms can obtain more than the guaranteed amount, thereby facing an upside risk that is not present in PVR contracts.

${ }^{12}$ Higher guaranteed growth rates were more expensive.

${ }^{13}$ The government argued that since its expectations of future demand growth were higher than those of the firms, there was space for mutually beneficial negotiations. The problem with this argument is that since there is no anchor to government expectations, it can always find room to renegotiate contracts with this method. The fact that the firm kept the upside risk means the instrument combined insurance against losses plus an option on
} 
Table 2: Income Distribution Mechanism (IMD) Contracts

\begin{tabular}{lcccr}
\hline Contract & $\begin{array}{c}\text { Payment by } \\
\text { franchise holder } \\
\text { [USD] }\end{array}$ & $\begin{array}{c}\text { No. months } \\
\text { until original } \\
\text { contract ends }\end{array}$ & $\begin{array}{c}\text { Guaranteed } \\
\text { revenue } \\
\text { [USD] }\end{array}$ & $\begin{array}{r}\text { Max. allowed } \\
\text { extension } \\
\text { (months) }\end{array}$ \\
\hline Camino de la Madera & $3,758,610$ & 199 & $42,764,005$ & 60 \\
Camino Nogales Puchuncaví & $1,647,695$ & 179 & $20,596,222$ & 60 \\
Ruta 5: Collipulli - Temuco & $28,217,149$ & 255 & $352.620,783$ & 100 \\
Ruta 5: Santiago - Talca & $82,461,394$ & 261 & $1,027,081,931$ & 100 \\
Ruta 5: Talca - Chillán & $32,432,399$ & 148 & $405,405,037$ & 100 \\
Ruta 5: Chillán - Collipulli & $22,239,631$ & 226 & $343,815,752$ & 60 \\
\hline Total & $170,756,879$ & & 2.192 .283 .731 & \\
\hline
\end{tabular}

Thus, the result was that the government exchanged additional current infrastructure against a guaranteed income that would be paid by future administrations.

It is worth noting that the government was quite explicit about why it renegotiated. It argued that the recession had reduced tax revenue and it could not afford to pay for additional public works for communities along the highways. ${ }^{14}$ Moreover, it argued that the losses had discouraged incumbent concessionaires from participating in new projects. ${ }^{15}$

\section{A simple model of renegotiations}

In the introduction we suggested a political economy model to explain renegotiations of franchise contracts. Our argument is based in three premises. First, an incumbent that spends more is more likely to be reelected. This implies that governments would like to anticipate expenditures. Second, budgetary rules and procedures, and parliamentary discussion of the budget constrain the extent to which governments can anticipate expenditures. Third, a renegotiation allows the incumbent to replicate the effect of a debt issue, while at the same time circumventing the normal appropriation procedure.

In what follows we present a simple model that formalizes this bias towards present spending, and show how the mechanism of infrastructure concessions allows the government to anticipate expenditures.

\footnotetext{
higher returns and cannot be valued solely as insurance.

14 "The government needed to build additional works in the concessioned infrastructure [and] did not have budget for the additional works.” Income Distribution Mechanism, Government of Chile, October 2005.

${ }^{15} \mathrm{As}$ we argue below, since the government is interested in increasing expenditure, this threat can be very effective.
} 


\subsection{Basic Set Up}

We consider a two-period model, where each "period" should be interpreted as the term of an administration. The discount factor equals 1 and social welfare is given by

$$
\mathscr{U}=u\left(I_{1}\right)+u\left(I_{2}\right)
$$

where $I_{t}$ denotes the capacity of the infrastructure in period $t$, and $u$ a strictly increasing, strictly concave function. ${ }^{16}$ For simplicity we assume that infrastructure fully depreciates in one period and that each unit costs $\$ 1$.

Available infrastructure projects are such that if $I_{t}$ units are provided in period $t, I_{t}$ users benefit. A subset of users is willing to pay at most $\$ 1$ each for using the infrastructure. We normalize the total number of users who are willing to pay in both periods to one, so that $I_{1}+I_{2} \leq 1$. Hence total intertemporal revenue cannot exceed 1 and if revenues equal to $I_{1}$ are generated in period 1 , then revenues in period 2 can at most equal $1-I_{1}$. This is a simple way of modeling the anticipation of spending: more spending today limits future spending and revenues.

Figure 1 depicts the time line of the game. There are two alternative ways of financing the infrastructure. Under the traditional model, Congress votes $I_{1}$ at the beginning of period 1 and allows the government to issue debt in that amount. Then the government selects the best private bid to build the infrastructure. At the end of the period, revenues equal to $I_{1}$ are collected from the users of the infrastructure and debts are paid. In period 2 the government issues debt equal to $I_{2}=1-I_{1}$ and the infrastructure is built. Then revenues are collected and the debt is paid. We assume that Congress maximizes social welfare, so that it optimally sets $I_{1}=I_{2}=\frac{1}{2} \cdot{ }^{17}$

The infrastructure can also be built and financed by a private firm, which then collects userfee revenue. In that case Congress sets $I_{1}=\frac{1}{2}$ at the beginning of the period, and the government allocates the concession in a competitive auction where firms bid for the total revenue $R_{1}^{c}$ they demand at the end of period $1 .{ }^{18}$

According to the franchise contract, at the end of the period the concessionaire will receive $R_{1}^{c}$, so that the government receives all user fees that aren't needed to pay off the franchise holder, namely $\phi \equiv \frac{1}{2}-R_{1}^{c}$ (the superscript $c$ denotes "contract"). The amount $\phi$ can be spent in period 2 in additional public works that generate no revenue from users. Neverthe-

\footnotetext{
${ }^{16}$ There are other interpretations for the concavity of utility: for example, assume that getting new international firms to participate is costly so there are no alternative suppliers for the firms already in the market. Since the increased expenditure increases the market power of the firms that already operate in the infrastructure franchise market, it is inefficient to cluster investments in the first period, because prices rise.

${ }^{17}$ The extension to allow for tax-financed infrastructure is straightforward.

${ }^{18}$ Alternatively, firms could bid on the user fee $f$ they charge. In that case, $R_{1}=f I_{1}$.
} 


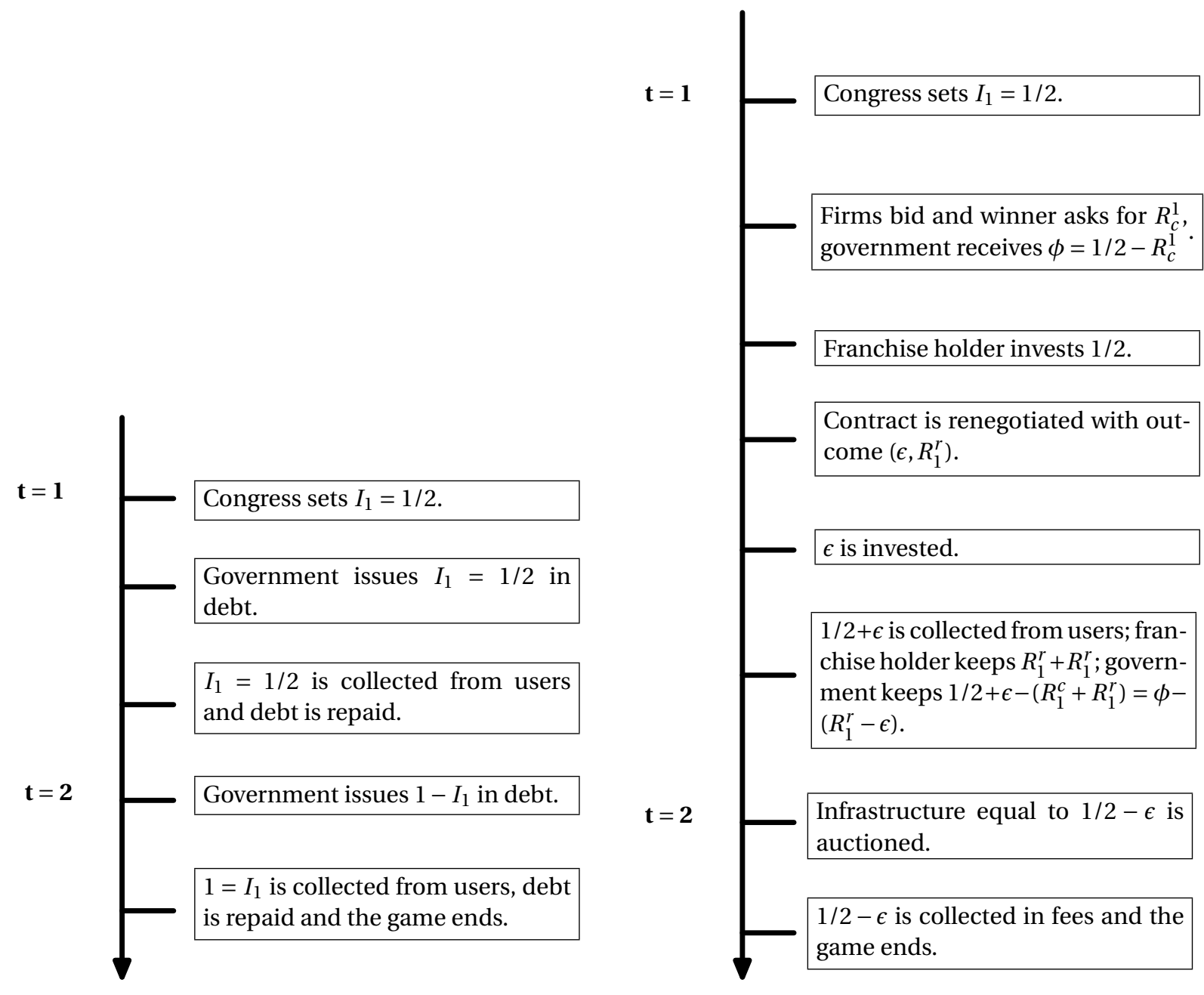

$\begin{array}{ll}\text { (a) Traditional infrastructure provision. } & \text { (b) PPP infrastructure provision. }\end{array}$

Figure 1: Timing of the infrastructure process 
less, after $\frac{1}{2}$ is invested in period 1 , the contract can be renegotiated without Congressional approval. An agreement leads to $\epsilon$ in additional works in the first period and $R_{1}^{r}$ in additional revenues for the concessionaire, where the superscript $r$ denotes "renegotiation". Hence, after renegotiation the concessionaire receives $R_{1}^{c}+R_{1}^{r}$ in revenue and the government receives

$\frac{1}{2}+\epsilon-\left(R_{1}^{c}+R_{1}^{r}\right)=\phi-\left(R_{1}^{r}-\epsilon\right)$, which is the difference between the value of the infrastructure and the payments to the firm.

In period 2 infrastructure equal to $1-\left(\frac{1}{2}+\epsilon\right)=\frac{1}{2}-\epsilon$ is auctioned and franchised. In addition, Congress allows the government to spend any excess of user-fee revenue over payments to the franchise holder it received in period 1 in non-revenue generating infrastructure. At the end of the period user fees are collected and the economy ends.

\subsection{The optimal solution for the government}

The government's objective function is:

$$
\mathscr{G}\left(I_{1}\right)=u\left(I_{1}\right)+p\left(I_{1}\right) u\left(1-I_{1}\right)
$$

where $p$ is the probability of being reelected. The probability $p$ takes values in $[0,1]$ and is an increasing and concave function of first period expenditure on infrastructure, $I_{1}$.

If unconstrained, the government would set $I_{1} \equiv I^{*}$ to satisfy the necessary FOC

$$
\frac{d \mathscr{G}}{d I}=u^{\prime}\left(I^{*}\right)+p\left(I^{*}\right) u^{\prime}\left(1-I^{*}\right)+p^{\prime}\left(I^{*}\right) u\left(1-I^{*}\right)=0
$$

with SOC

$$
\frac{d^{2} \mathscr{G}}{d I^{2}}=u^{\prime \prime}\left(I^{*}\right)+p\left(I^{*}\right) u^{\prime \prime}\left(1-I^{*}\right)-2 p^{\prime}\left(I^{*}\right) u^{\prime}\left(1-I^{*}\right)+p^{\prime \prime} u\left(1-I^{*}\right)<0,
$$

where we used that $u$ and $p$ are concave and increasing.

We now show that $I^{*}>1 / 2$. To begin, assume that $p^{\prime}=p^{\prime \prime}=0$, that is, there is a fixed probability of reelection $p \in[0,1]$. Denote the corresponding optimal investment in infrastructure during period 1 by $I^{p}$.

The FOC then simplifies to

$$
u^{\prime}\left(I^{p}\right)+p u^{\prime}\left(1-I^{p}\right)=0 .
$$


Simple differentiation then shows that

$$
\frac{d I^{p}}{d p}=\frac{u^{\prime}\left(1-I^{p}\right)}{u^{\prime \prime}\left(I^{p}\right)+p u^{\prime \prime}\left(1-I^{p}\right)}<0
$$

Hence, $I^{p}>I^{*}$ for $p<1$. This result is well known (see Alesina and Tabellini [1990]): the current government tends to anticipate spending because it bears the cost of it-less future spendingwith probability less than one.

We return to the first order condition (2) with $p$ a function of $I$. We define $p^{\text {eq }}$ so that

$$
u^{\prime}\left(I^{*}\right) \equiv p^{\mathrm{eq}} u^{\prime}\left(1-I^{*}\right)
$$

that is, $p^{\mathrm{eq}}$ is the fixed probability such that the current government would optimally choose to spend $I^{*}$. Now from the FOC (2) we have

$$
u^{\prime}\left(I^{*}\right)=p\left(I^{*}\right) u^{\prime}\left(1-I^{*}\right)-p^{\prime}\left(I^{*}\right) u\left(1-I^{*}\right) .
$$

It follows that

$$
p^{\mathrm{eq}}=p\left(I^{*}\right)-p^{\prime}\left(I^{*}\right) \frac{u\left(1-I^{*}\right)}{u^{\prime}\left(1-I^{*}\right)} .
$$

Hence $p^{\mathrm{eq}}<p\left(I^{*}\right)$ and $I^{*}>I^{p^{*}}>1 / 2$, where $I^{p^{*}}$ denotes optimal government expenditure for a government with constant $p$ equal to $p\left(I^{*}\right)$.

Thus, there are two reasons why the current government wants to anticipate spending. The first is that the coalition may not be in office in the future: $p<1$ acts as a (socially inefficient) discount rate. And second, more spending today increases the probability of reelection. The latter implies that the government's expenditure level not only depends on its probability of being re-elected, $p\left(I^{*}\right)$, but also on how responsive this probability is to changes in expenditures. A more responsive probability leads to higher expenditures, even when the actual probability of being re-elected remains unchanged.

\subsection{Implementation of the government's investment plan}

With the traditional model, in period 1 the government is constrained by Congress to issue $\frac{1}{2}$ in debt and procure $\frac{1}{2}$ in infrastructure capacity. By contrast, we will show that a concession contract allows the government to renegotiate the contract, anticipate spending and implement its optimum.

Assume that in period 1 the contract can be renegotiated after investment equal to $\frac{1}{2}$ is sunk. 
If the incumbent and the concessionaire agree to $\epsilon$ in additional works against $R_{1}^{r}$ in additional revenues, the concessionaire now receives

$$
R_{1}^{c}+R_{1}^{r}
$$

and spends $\frac{1}{2}+\epsilon$. The incumbent, in turn, gets $\frac{1}{2}+\epsilon$ in investment in period 1 , and $\frac{1}{2}+\epsilon-\left(R_{1}^{c}+\right.$ $\left.R_{1}^{r}\right)=\phi-\left(R_{1}^{r}-\epsilon\right)$ in user-fee revenues, which can be used in period 2 . Hence after renegotiation his utility increases to

$$
u\left(\frac{1}{2}+\epsilon\right)+p\left(\frac{1}{2}+\epsilon\right) u\left(\frac{1}{2}-\epsilon+\phi-\left(R_{1}^{r}-\epsilon\right)\right)
$$

Competition in the auction and rational expectations on the part of the bidders for the concession implies that $\phi=R_{1}^{r}-\epsilon$ in equilibrium. That is, the winner of the auction offers a bid that lowballs the price to equal his expected gain in the renegotiation process. Hence, the incumbent's utility is

$$
u\left(\frac{1}{2}+\epsilon\right)+p\left(\frac{1}{2}+\epsilon\right) u\left(\frac{1}{2}-\epsilon\right) .
$$

Note that the renegotiation allows the incumbent to achieve a debt-like intertemporal transfer. Infrastructure spending in period one rises by $\epsilon$, at the cost of $\epsilon$ less infrastructure spending in period two.

What will be the outcome of the renegotiation? Note that the incumbent administration can always achieve utility $u\left(\frac{1}{2}\right)+p\left(\frac{1}{2}\right) u\left(\frac{1}{2}+\phi\right)$, because if no agreement is reached, it invests $\frac{1}{2}$ in the first period and receives revenues $\phi$, which can be spent in period 2, so this is its threatpoint. Let $\widetilde{\epsilon}$ denote the extra investment that maximizes (3). Then, in utility terms, the surplus to be split between the incumbent and the firm is

$$
\mathscr{S}(\phi, \widetilde{\epsilon})=u\left(\frac{1}{2}+\widetilde{\epsilon}\right)+p\left(\frac{1}{2}+\widetilde{\epsilon}\right) u\left(\frac{1}{2}-\widetilde{\epsilon}\right)-\left[u\left(\frac{1}{2}\right)+p\left(\frac{1}{2}\right) u\left(\frac{1}{2}+\phi\right)\right]
$$

where we have used the fact that $\phi=R_{1}^{r}-\epsilon$ in equilibrium. To transform this surplus into monetary units, let $\bar{\phi}$ be the value of $\phi$ such that $\mathscr{S}(\bar{\phi}, \widetilde{\epsilon}(\bar{\phi})) \equiv 0$, i.e., $\bar{\phi}$ measures the maximum value of an agreement, in monetary terms, as a function of $\widetilde{\epsilon}$.

If no agreement is reached, the government can keep the $\phi$ it collects in the first period. It follows that the monetary surplus that is split equals $\bar{\phi}-\phi$. In general the solution to the bargaining problem is such that if the firm's Nash bargaining power is $\alpha$, it will receive a fraction of total surplus $\alpha(\bar{\phi}-\phi)$, Because competition in the auction implies that $\phi=\alpha(\bar{\phi}-\phi)$ it follows 
that $^{19}$

$$
\phi=\frac{\alpha}{1+\alpha} \bar{\phi}
$$

When the government has all the bargaining power $\alpha=0$, and the firm gets nothing. Conversely, if the firm has all the bargaining power, $\alpha=1$ and it gets all the surplus, which equals $\bar{\phi} / 2 .^{20}$

The derivation above is valid for any value of $\widetilde{\epsilon}$. Next we show that in equilibrium the incumbent chooses $\widetilde{\epsilon}=\epsilon^{*} \equiv I^{*}-1 / 2$.

Proposition 1 In equilibrium the incumbent administration implements its optimal investment plan, regardless of the distribution of bargaining power.

Proof Efficient bargaining implies that the optimal increase in current infrastructure spending will maximize

$$
u\left(\frac{1}{2}+\epsilon\right)+p\left(\frac{1}{2}+\epsilon\right) u\left(\frac{1}{2}-\epsilon+\phi-\left(R_{1}^{r}-\epsilon\right)\right)
$$

The FOC will satisfy

$$
u^{\prime}\left(\frac{1}{2}+\widetilde{\epsilon}\right)+p^{\prime}\left(\frac{1}{2}+\widetilde{\epsilon}\right) u\left(\frac{1}{2}-\widetilde{\epsilon}\right)-p\left(\frac{1}{2}+\widetilde{\epsilon}\right) u^{\prime}\left(\frac{1}{2}-\widetilde{\epsilon}\right)\left(1+\frac{d\left(R_{1}^{r}-\epsilon\right)}{d \epsilon}\right)=0,
$$

where we have used the fact that $\phi-\left(R_{1}^{r}-\widetilde{\epsilon}\right)=0$ in equilibrium. Also, in equilibrium

$$
R_{1}^{r}-\widetilde{\epsilon}=\phi=\frac{\alpha}{1+\alpha} \bar{\phi}
$$

It is clear from (4) that $\bar{\phi}$ is maximized when $\widetilde{\epsilon}=\epsilon^{*}$. Thus efficient bargaining implies that $\frac{d\left(R_{1}^{r}-\epsilon\right)}{d \epsilon}=0$ when evaluated at $\epsilon=\epsilon^{*}$. Hence, $\widetilde{\epsilon}=\epsilon^{*}$, which completes the proof.

The result above shows that renegotiation allows the incumbent to replicate its desired timing of infrastructure expenditure spending, while the concessionaire obtains better terms ex post. It is true that the incumbent could replicate the same outcome under the traditional appropriations model, if it could credibly commit to transfer to buyers of debt the increased user-fee income generated by the $\epsilon$ additional construction. But here congressional oversight

\footnotetext{
${ }^{19}$ Note that in this expression, $\phi$ is a function of $\epsilon^{*}$.

${ }^{20}$ Even when it has all the bargaining power, the firm gets $\bar{\phi} / 2$ and not $\bar{\phi}$. The reason is that $\bar{\phi}$ does not belong to the set of values of $\phi$ that can be attained as equilibrium outcomes of our model. The franchise holder lowballs by $\phi$ when it competes to procure the infrastructure approved by congress in the first period, $1 / 2$, in the expectation of recuperating this additional payment when it later renegotiates. Yet this extra payment, $\phi$, in turn bounds away from zero the government's benefit from a renegotiation, even when it has no bargaining power. Thus, when $\alpha=1$, the firm obtains all the ex-post surplus, $\bar{\phi}-\phi$, which is less than the surplus created by a renegotiation, $\bar{\phi}$.
} 
is important and makes a difference. If Congress does not allow it, the government cannot credibly commit to earmark the revenue generated by the additional infrastructure to pay the additional debt (since the additional works were not authorized). By contrast, a renegotiated concession contract credibly earmarks the revenues generated by the infrastructure-a renegotiated contracts is enforceable in court. Of course, Congress could eventually limit this tendency by overseeing renegotiations. But given current budgetary practices, this "debt" escapes the normal budgetary process and allows the incumbent to anticipate spending.

Finally, note that our formal analysis is based on the premise that governments renegotiate with existing franchise holders. Why bargain with current franchise holders and favor them instead of calling a competitive auction for the $\epsilon$ additional works? There are at least two reasons. One is that the source of funds to compensate a franchise holder is straightforward-improving the original deal with a term extension, a user-fee increase or a reduction in investment obligations. As we have mentioned, a renegotiated contract is enforceable and thus creditworthy. Moreover, current franchise holders have a short term monopoly over the bidding for new franchises, for a number of reasons. First, in small countries where franchise holders are international firms, those that have already invested in franchises are acquainted with the regulations, norms and procedures and have some experience on how the country is run, so they have an advantage over new entrants. ${ }^{21}$ Furthermore, the fact that current franchise holders do not want to participate in bidding for new franchises reinforces the fears of new foreign entrants. Hence, it might take a fairly long time, before the government can convince new firms to participate in new franchise projects. Given the short span of the political time frame, this provides current franchise holders with the ability to hold up the current government. Their threat is that they will not participate in new projects, which means that such projects will be delayed until the government can attract new bidders (which may be after the election takes place).

\subsection{An extension: stochastic renegotiation}

A more realistic situation for the government is that the election is in doubt only in certain cases, while in others it is fairly certain that it will be reelected. In the case of certain reelection, the government prefers not to distort the allocation of expenditure across periods, since it will be in power with certainty in the next period. With exogenous probability $\pi$, however, there is a shock which makes for a weak government whose reelection probability depends in part on its

\footnotetext{
${ }^{21}$ These arguments are similar to those used in the theory of foreign direct investment, as in Dunning (1981).
} 
infrastructure investments in the first period. We model this as:

$$
\mathscr{G}\left(I_{1}\right)=u\left(I_{1}\right)+p^{e}\left(I_{1}\right) u\left(1-I_{1}\right)
$$

where $p^{e}(I) \equiv \pi p(I)+(1-\pi) 1$ is a weighted average of the two probability functions. Now since the winning bidder in the project will be able to renegotiate with probability $\pi$, the first period reduction in price will be $\pi \phi$.

If the government does not need to renegotiate, which occurs with probability $1-\pi$, it obtains welfare $u\left(\frac{1}{2}\right)+u\left(\frac{1}{2}+\pi \phi\right)$, because in the second period it can spend the savings it made in the first period. On the other hand, if the shock occurs, with probability $\pi$, we can use the analysis of the previous section to obtain the surplus it obtains by renegotiating. This surplus is the same as the one defined by (4), with $\pi \phi$ replacing $\phi$. Since renegotiation occurs after the shock, the surplus is not altered by the fact that the government might have avoided renegotiation. Then:

$$
\hat{\mathscr{S}}(\phi ; \pi)=u\left(\frac{1}{2}+\epsilon^{*}\right)+p\left(\frac{1}{2}+\epsilon^{*}\right) u\left(\frac{1}{2}-\epsilon^{*}\right)-\left[u\left(\frac{1}{2}\right)+p\left(\frac{1}{2}\right) u\left(\frac{1}{2}+\pi \phi\right)\right]
$$

We define $\bar{\phi}(\pi)$ as the value of $\phi$ such that $\hat{\mathscr{S}}(\phi ; \pi)=0$, and proceed as before. Then, assuming that the firm has bargaining power $\alpha$, it gets $\phi(\pi)=\alpha(\bar{\phi}(\pi)-\pi \phi)$, which leads to

$$
\phi=\frac{\alpha}{1+\alpha \pi} \bar{\phi}(\pi)
$$

It is easy to see that $\phi^{\prime}(\pi)<0$, i.e., as it becomes more likely that the government needs to renegotiate, the ex-post rents to the firm become smaller. The additional revenue obtained by the firm when it renegotiates must compensate for its upfront payments on occasions where no renegotiation takes place. The smaller the probability of renegotiation, the larger the compensation needed when renegotiations do occur.

\section{Conclusion: The puzzle of renegotiation}

Renegotiations allow incumbents to increase spending in ways that increase their chances of reelection. Hence, aside from the traditional view, which appeals to corruption or incompetence to explain renegotiations that favor concessionaires, we add a political economy explanation. Renegotiations allow the government to increase current expenditures, to be paid with future income, be it in the form of higher user-fees, longer concession terms or future taxes. It is a means of getting the political advantages from increased infrastructure spending while 
circumventing the constraints imposed by the normal budgetary process. This is attractive for governments which face the possibility of losing an election, and explains why infrastructure contracts are renegotiated when there is no obvious holdup problem.

Can something be done to moderate the tendency of using renegotiations to anticipate spending? A natural option is to set up independent oversight agencies to review renegotiations. Which brings us to the institutional framework set up to run the concessions program. Incentives to anticipate expenditures are particularly relevant when the ministry of public works is in charge of the franchising program. One obvious reason is that the purpose of such an agency is, essentially, to build new projects. If the agency is given leeway to renegotiate projects, it will probably use them to expand the public works program. These incentives are strengthened by the fact that the ex post rent the concessionaire obtains by renegotiating is determined in an off the budget process. Hence, the agency in charge of building public works does not internalize the costs of renegotiations, just as the current government does not fully internalize the future costs of its current policies. 


\section{References}

[1] Alesina, A. and G. Tabellini, "A Positive Theory of Fiscal Deficits and Government Debt," Review of Economic Studies 57, 403-414, 1990.

[2] Dunning, J., International Production and the Multinational Enterprise, London, George Allen and Unwin, 1991.

[3] Engel, E., R. Fischer and A. Galetovic, "Least Present Value of Revenue Auctions and Highway Franchising," Journal of Political Economy 109, 993-1020, 2001.

[4] Gómez-Ibáñez, J. and J. Meyer, Going Private: The International Experience with Transport Privatization. Washington: The Brookings Institution, 1993.

[5] Guasch, J.L., Granting and Renegotiating Infrastructure Concessions: Doing it Right. WBI Development Studies. Washington: The World Bank, 2004.

[6] Guasch, J.L., J.J. Laffont and S. Straub, "Renegotiation of Concession Contracts in Latin America," Washington: The World Bank, 2003.

[7] Hart, O. Firms, Contracts and Financial Structure. Oxford, Clarendon Press, 1995. 